\title{
CORROSION PROCESSES OF AUSTENITIC STAINLESS \\ STEELS AND COPPER-BASED MATERIALS IN \\ GAMMA-IRRADIATED AQUEOUS ENVIRONMENTS
}

Robert $S$. Glass

Richard A. Van Konynenburg

George E. Overturf

This paper was prepared for submittal to:

Corrosion $/ 86$

Albert Thomas Cenvention Center

Houston, Texas, March 17-21, 1986

September 1985

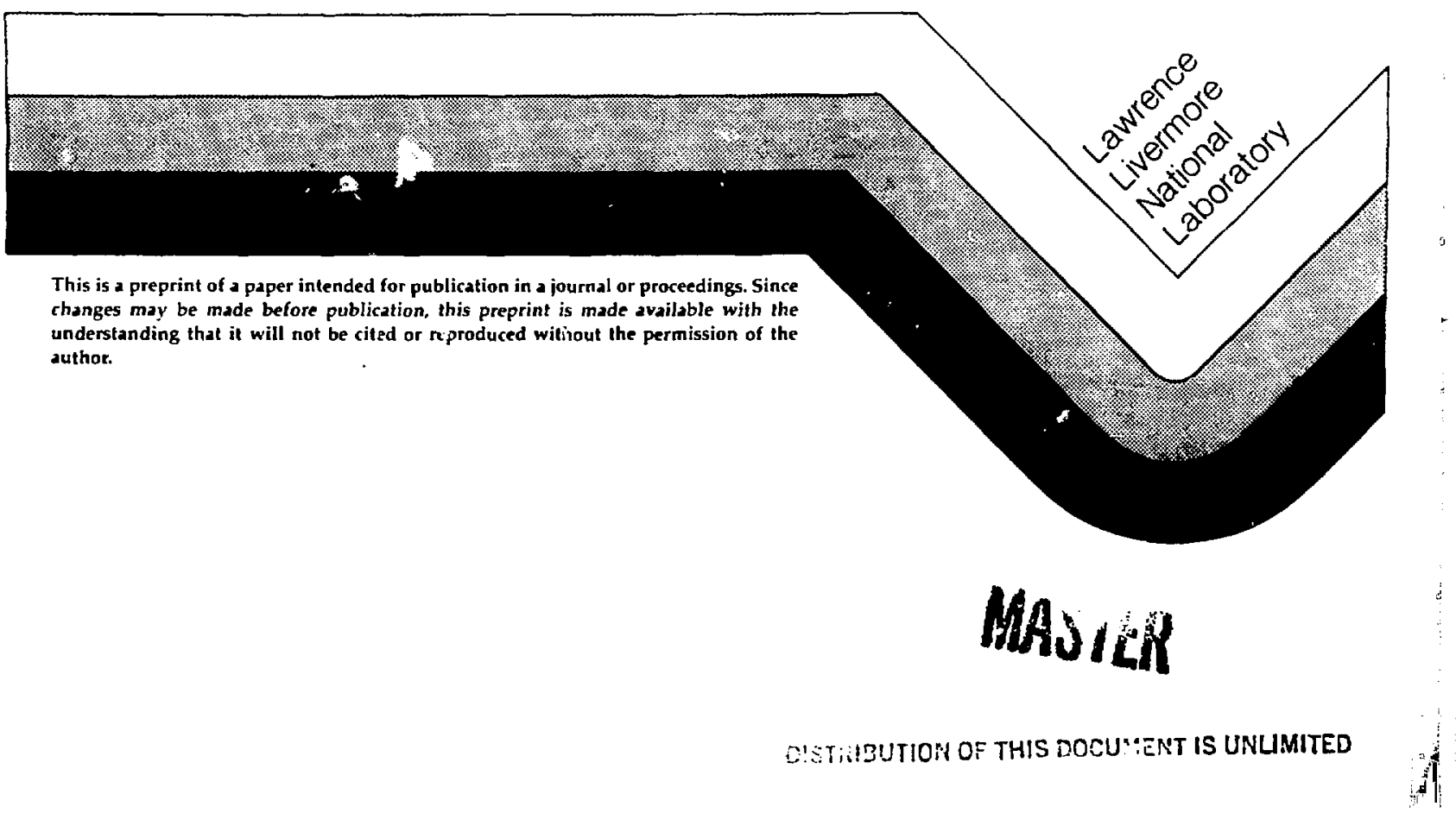




\title{
DISCLAIMER
}

This report was prepared as an account of work sponsored by an agency of the United States Government. Neither the United States Government nor any agency thereof, nor any of tbeir employetes, makes any warranty, express or implied, or assumes any legal tiability or responsibility for the accuracy, completeness, or usefulness of any information, apparatus, product, or process disclosed, or represents that its use would not infringe privately owned rights. Refeence herein to any specific commercial product, process, or service by trade name, trademark, manufacturer, or otherwise does not necessarily constitute or imply its endorsement, recommendation, or favoring by the United States Government or any agency thereof. The views and opinions of authors expressed herein do not necessarily state or reflect thoec of the United States Government or any agency thereof.

\section{CORROSION PROCESSES OF AUSTENITIC STAINLESS STEELS AND COPPER-BASED}

MATERIALS IN GAMMA-IRRADIATED AQUEOUS ENVIRONR,ENTS ${ }^{(1)}$

\author{
Robert S. Glass \\ Lawrence Livermore National Laboratory \\ P. O. Box 808 \\ Livermore, $C A \quad 94550$ \\ Richard A. Van Konynenburg \\ George E. Overtur $f$
}

\section{ABSTRACT}

The U. S. Department of Energy is evaluating a site located at Yucca Mountain in Nye County, Nevada, as a potential high-level nuclear waste repository. The rock at the proposed repository horizon (above the water table) is densely welded, devitrified tuff, and the fluid environment in the repository is expected to be primarily air-steam. A more severe environment would be present in the unlikely case of intrusion of vadose groundwater into the repository site. For this repository location, austenitic stainless steels and copper-based materials are under consideration for waste container fabrication. This study focuses on the effects of gamma irradiation on the electrochemical mechanisms of corrosion for the prospective waste container materials. The radiolytic production of such species as hydrogen per-

(1) Work performed under the auspices of the U.S. Department of Energy by the Lawrence Livermore National Laboratory under contract number W-7405-ENG-48. oxide and nitric acid are shown to exert an influence on corrosion mechanisms and kinetics.

\section{INTRODUCTION}

The permanent disposal of high level nuclear waste materials is a current technological challenge. For geologic disjosal, the U. S. Nuclear Regulatory Commission regulations require packages that provide "substantially complete" waste containment for time periods of 300 to 1000 years.

Currently, the U. S. Department of Energy is evaluating a site located at Yucca Mountain in Nye County, Nevada, as a potential high-level nuclear waste repository. The reck at the repository horizon is densely welded, devitrified tuff. For this repository location, austenitic stainless steels (e.g. . AISI $304 \mathrm{~L}$ and $316 \mathrm{~L}$ ) are the primary materials under evaluation for use as potential waste containers. Also under consideration as waste canister materials are copper and some of its alloys, namely the 
cupronickels and aluminum bronzes. Copper is thermodynamically stable in certain aqueous geological enviroments. However, the oxidizing nature of the environment in a tuff repository in the unsaturated zone, in combination with the effects of gamma irradiation, may present more corrosive conditions for these materials than for austenitic stainless steels.

For the proposed repository, the fluid enviconment is expected to be primarily air-steam. A more severe-case environment for the waste packages would be present if vadose groundwater intruded into the repository site. This is thought to be unlikely, but still needs to be considered. The low annual prec1pitation at the site and low rate of percolation of water downward would minimize the actual amount of witer entering the waste package environment. In addition, the heat generated from the nuclear waste would vaporize incoming water at temperatures above $95^{\circ} \mathrm{C}$ (boiling point of water at the repository elevation). For the large majority of waste packages, container surface temperatures woula be expected to remain above $95^{\circ} \mathrm{C}$ for several hundreds of years.l

In addition to groundwater that contains naturally occurring concentrations of dissolved species, it is also of interest to consider solutions in which these species are more concentrated. Evaporative processes at the repository site could lead to concentration of the electrolyte, by a mechanism such as the following: Groundwater might intrude into the repository site prior to the time that the container surface had cooled to below boiling temperature. It would then fvaporate and leave behind salt deposits. Subsequent repetition of these events at the same locations could conceivably result in local salt builoup. When the container surface temperature later cooled to below the boiling point, further wetting at locations of salt build-up could lead to a concentrated electrolyte.

In designing metallic engineered barriers for waste disposal, one must evaluate the susceptibility to fa:lure modes normally encountered in corrosion studies (e.g., uniform corrosion, pitting, crevice attack, and stress cor- rosion cracking). In so doing, it is necessary to understand the interaction of gamma radiation from the nuclear waste with the surrounding chemical environment in light of possible effects on corrosion mechanisms. These latter effects are just beginning to be explored for potential repository sites.

Previous investigations have found an increased susceptibility of sensitized AISI 304 stainless steel towards intergranular stress corrosion cracking in high temperature water under gamma irradiation. 2,3 other reports have claimed an increased resistance to crevice corrosion for austenitic stain'ess steels in aqueous solutions under gamma irradiation. 4 For carbon steel and AISI 304 stainless steel, gamma irradiation in high temperature $\left(250^{\circ} \mathrm{C}\right)$ water containing low oxygen levels has been shown to increase the release rates of insoluble corrosion products but not to increase the release rates of soluble products. 5

Several reports have demonstrated effects of gamma irradiation on the corrosion potentials of austenitic stainless steels in aqueous media. $5,6-10$ However, in general, a fundamental understanding of the effects of gamma irradia$t$ ion on the mechanisms of corrosion of austenitic stainiess steels and copper alloys is lacking. In particular, ir. aqueous environments having near-neutral $\mathrm{pH}$, tho introduction of new electrochemical reactions by the radiolyticallygenerated oxidants has received little machanistic investigation. However, specias such as $\bullet \mathrm{OH}, \mathrm{H}_{2} \mathrm{O}_{2}, \mathrm{O}_{2}, \mathrm{HO}_{2}$, and $\mathrm{o}_{\overline{2}}$, which are generated radiolytically, are generally ascumed to increase the oxidizing nature of the environment.

In this study, in-situ electrochemical measurements have been made of corzosion potential shifts produced by gamma irradiation. These potential shifts are in the positive direction and reflect the production of such oxidizing species as - OH and $\mathrm{H}_{2} \mathrm{O}_{2}$. The detailed nature of the interfacial electrochemical mechanisms responsible for these potential shifts is being explored for austenitic stainiess steels and copper alioys. In addition, the alterations in the susceptibility to lovalized corrosion (e.g.. pitting and crevice corrosion) are being 
evaluated by in-situ anodic polarization curves and occluded cell experiments. which will be described elsewhere.

\section{EXPERIMENTAL}

In this section the experimental details are briefly sumarized. A more detaileć description is provided elsewhere. 10

Rods of both AISI 316L stainless stee) $(0.02 \mathrm{C} ; 1.71 \mathrm{Mn} ; 0.033 \mathrm{P} ; 0.014 \mathrm{~S}$; $0.56 \mathrm{Si} ; 10.29 \mathrm{Ni} ; 16.51 \mathrm{Cr} ; 2.07 \mathrm{Mo}$; $0.10 \mathrm{Co} ; 0.28 \mathrm{Cu} ; 0.054 \mathrm{~N}$, bal. Pe) and Type CDAl02 copper (>99.958 Cu) were used as the working electrodes. Thermomechanical treatment was as-received. All samples were polished to at least $1 \mathrm{H}$ finish with $\mathrm{Al}_{2} \mathrm{O}_{3}$ slurries prior to use.

The groundiater used in these experiments was obtained from Well J-13, which is located near the repository site. The J-13 well penetrates the same tuff formation below the water table, at a lower elevation than that of the proposed repository site. The composition of the croundwater is shown in Table I. Analyses of the constituents were made by ion chromatography, inductively-coupled plasma emission spectroscopy, and Technicon AutoAnalyzer. In some experiments, concentrated forms of this groundwater (10x and 100x) were used. Boildown under atmospheric pressure was used to obtain the more concentrated electrolytes.

The electrochemical apparatus used in this work consisted of two chambers. The reference electrode (SCE) was placed in a reservoir containing saturated $\mathrm{KCl}$ in the upper chamber. The upper and lower chambers were connected by a luggin probe, approximately $1.4 \mathrm{~m}$ long, and terminating $w i t h$ a pornus vicor tjp, filled with saturated $\mathrm{KCl}$. The lower chamber, which was the only part of the system surrounded by the gamma ray sources, contained the Pyrex electroshemical cell. The coli itself had ports for the reference electrode Luggin probe, the working electrode, a counter electrude and an inlet for deateration. In this arrangehent the reference electrode was isolated front the qamma ray sources.

The gamma ray sources consisted of stainless-steel-encansulated $6^{\circ}$ Co pencils in a cylindrical (napkin ring) arrangement. The lower chamber of the electrochemical apparatus was inserted into the inside of the cylinder, at the center of which the dose rate was $3.3 \mathrm{Mrad} / \mathrm{hr}( \pm 208)$. All experiments were performed at $30^{\circ} \mathrm{C}$ $\left( \pm 5^{\circ} \mathrm{C}\right)$.

Open-circuit potential vs time and anodic polarization curves were obtained with the eid of a Princeton hpplied Research Model 173 potentiostat and a Model 176 current-to-voltage converter.

\section{RESULTS AND DISCUSSION}

Aqueous Environment and Radiation Chemistry

Before proceeding to interpret the electrochemical experiments, it is helpful to consider present knowledge of the bulk radiation chemistry of aqueous solutions from past work in this field. Because the groundwater contains only low concentrations of solutes, most of which do not undergo high-rate reactions with radiolytic radicals, its initial radiation chemistry should be simiiar to that of pure water. The interaction of gamma radiation with aqueous environments pruduces a host of transient radicals, ions, and stable molecular species including $H$, ' $\mathrm{GH}, \mathrm{e}_{\mathrm{a}}^{-}, \mathrm{H}_{3} \mathrm{O}^{+}, \mathrm{OH}^{-}, \mathrm{in}_{2}, \mathrm{H}_{2} \mathrm{O}_{2}, \mathrm{O}_{2}, \mathrm{O}_{\overline{2}}$. and $\mathrm{HO}_{2}, 11-13$ species sich às éag, $\mathrm{H}^{\circ}$, and $\mathrm{H}_{2}$ can act as reducing agents, while others, suin as $\mathrm{H}_{2} \mathrm{O}_{2}, \cdot{ }^{\circ} \mathrm{OH}, \mathrm{O}_{2}, \mathrm{O}_{2}$ and $\mathrm{HO}_{2}$, can act as oxiàizing agents. As a result of the production of such active species under gamma irradiation; one can expect alterations in the rates or mechanisms of corrosion attack modes.

Under radiolysis of air-saturated $\mathrm{J}-13$ well wacer or $j$ ts concentrated forms (e.g., up to $100 x$ concentration), we expect an oxidizing environment with $\mathrm{O}_{2}$ and $\mathrm{H}_{2} \mathrm{O}_{2}$ as the dominant oxidizing species, a much smaller concentration of $0_{2}$ and still much smaller steady-state concentrations of $\mathrm{HO}_{2}, \cdot{ }^{\circ} \mathrm{OH}, \mathrm{H}_{2}, \mathrm{e}$ aq' and $H \cdot .10$ In addition to these species, various oxides of nitrogen and nitric acid are capable of being formed in a moist air phase, if one is present. and subsequently entering the solution. Irradiation of water containing either $\mathrm{CO}_{2}$ or $\mathrm{HCO}_{3}^{-}$with $\mathrm{O}_{2}$ gives rise to pro- 
duction of carboxylic acids (formic and/ or oxalic).

Pote.tial Measurements and Elect $\downarrow$ ochemical Mechanisms

This section will be divided into the results obtained for AISI 316L stainless steel and those for Type CDA102 copper. A more comprehensive discussion of the electrochemistry of austenitic stainless steels in irradiated environments can be found elsewhere. 10

\section{Austenitic Stainless Steels}

As a result of the production of a more oxidizing environment under gamma irradiation, the corrosion potentials of austenitic stainless steels are shifted in the positive direction. Such a result for AISI $316 \mathrm{~L}$ in $10 x$ concentrated $\mathrm{J}-13$ is shown in Fig. 1. In this figure, "on" refers to lowering of the cell into the center of the gamma ray sources and "off" refers to raising the cell 1.3 to $1.5 \mathrm{~m}$ above the sources, where the cell was shielded by intervening water. Several "on/off" cycles are shown. Similar posi-ive potential shifts upon imposition of the gamma field were observed for AISI $316 \mathrm{~L}$ in more highly concentrated groundwater (e.g., 100x), and in non-concentrated $\mathrm{J}-13$ well water, and with AISI 304L stainless steel as the electrode material. The corrosion potential shifts under all these conditions and for both materials were typically 150-200 mV.

Following exposure of AISI 316L to gamma-irradiated environments, the electrochemical cell was removed from the gamma sources and the corrosion potential was continuously monitored for several hours (generally more than 14 hours). The potential in each case was found to remain in the range of the high (relative) positive values that were observed immediately after termination of the irradiation.

In order to test whether the observed effects resulted from stable oxidizing species in the solution or from permanent changes in the oxide film on the electrode, the following experiment was performed: Following several "on/off" cycles for Type 316L stainless steel in J-13 water, the cell was removed from the gamma facility and the irradiated solution was replaced by "fresh" non-irradiated $\mathrm{J}-13$ water. When this was done, the corrosion potential immediately shifted in the negative direction (see Fig. 2). This indicates that the initial positive potential shifts observed were due principally to radiolytically generated stable oxidizing species rather than to oxide film changes. If the latter had been the case, the oxitie layer would not have been expected to change back to its original state when the solution was replaced, particularly not as rapidly as the observed change in potential occurred.

As discussed above, $\mathrm{H}_{2} \mathrm{O}_{2}$ is the dominate stable cxidizing species produced under radiolysis. In $\mathrm{J}-13$, following 3.5 hours of exposure at the dose rate employed in this study, we measured the concentration of $\mathrm{H}_{2} \mathrm{O}_{2}$ produced to be $0.14 \mathrm{~mm}$ using the titanium oxalate method.14 To see whether $\mathrm{H}_{2} \mathrm{O}_{2}$ alone could produce tt.e potential shifts of the magnitude observed under irradiation, one drop of $308 \mathrm{H}_{2} \mathrm{O}_{2}$ solution was added to the fresh $\mathrm{J}-13$ water in the cell from the experiment above, producing a concentration of about $4.4 \mathrm{mM}$. The potential was observed to shift in the positive direction immediately (see Fig. 2). The observed change when $\mathrm{H}_{2} \mathrm{O}_{2}$ was added to the solution, coupled with the knowledge that $\mathrm{H}_{2} \mathrm{O}_{2}$ is the most concentrated radiolytic species present in an irradiated, aerated solution, provides strong evidence that it is responsible for the potential shift observed upon irradiation in these solutions.

In a similar experiment, successive additions of $308 \mathrm{H}_{2} \mathrm{O}_{2}$ solution were made to an unirradiated $\mathrm{J}-13$ solution in which a freshly prepared AISI $316 \mathrm{~L}$ electrode was immersed. The results of this experiment are shown in Fig. 3. In this figure, a one-drop addition to the solution represents a concentration increase of approximately $0.5 \mathrm{mM}$, which is near the $0.14 \mathrm{~mm}$ concentration which was experimentally measured under the conoitions above. It can be seen that the potential shift observed following the addition of the first drop is near the bot.tom end of the range of potential shifts observed under radiolysis $(150-200 \mathrm{mV})$. These results add further suport to the 
interpretation that the production of $\mathrm{H}_{2} \mathrm{O}_{2}$ under radiolysis leads to the longterm potential shifts observed. However, the production of other oxidizing species (e.g.. - OH) under radiolysis will also assist in producing positive polential shifts.

\section{CDA102 Copper}

Although some of the general features (e.g., positive corrosion potential shifts) are similar, the behavior of copper in gamma-irradiated environments differs from that of stainless steel. Figure 4 shows the corrosion potential vs. time behavior of CDA.102 in $\mathrm{J}-13$ water when subjected to garuma irradiation. Upon initiation of irradiation the corrosion potential jumped approximately $100 \mathrm{mV}$ positive, then rapidly decayed to more negative values. If achievement of steady-state had been allowed, the Einal potential probably would have reached nearly the same value as that attained prior to irradiation for at most $10-20 \mathrm{mV}$ highe $r$ ). This is in contrast to the much larger and longer term potential shifts observed for stainless steels in this medium. upon termination of irradiation, the corrosion potential dropped (in the negative direction), which is analogrus to the behavior with stainless steels. Results similar to those for CDA102 were obtained for the copper alloy CDA715 (70 $\mathrm{Cu}-30 \mathrm{Ni}$ ).

A similar corrosion potential vs time relationship was ubserved when $\mathrm{H}_{2} \mathrm{O}_{2}$ was added to unirradiated $\mathrm{J}-13$ water in which a CDAI02 electrode was immersed. Results of this experiment are shown in $\mathrm{Eig.} \mathrm{5.} \mathrm{In} \mathrm{this} \mathrm{figure,} \mathrm{one} \mathrm{drop} \mathrm{of} \mathrm{a}$ $308 \mathrm{H}_{2} \mathrm{O}_{2}$ solution again represents a resulting concentration in J-13 water of approximately $0.5 \mathrm{mM}$. The solution was stirred during the adaition of $\mathrm{H}_{2} \mathrm{O}_{2}$.

The similarity of the potential rise and decay observed in Figs, 4 and 5 for copper indicates that the radiolytic product $\mathrm{H}_{2} \mathrm{O}_{2}$ is a major ceterminant of the electrochemical behavior of copper in irradiated enviconments, as it is for AISI 316L stainless steel. It is noted that the initial potential rise and the apparent steady-state potential after the decay are more posirive in the exsitu case (Fig. 5) tho-1 in the irradia- tion experiment (Fig. 4). This is probably because the concentration of $\mathrm{H}_{2} \mathrm{O}_{2}$ added in the ex situ experiment was a factor of 3 to 4 times higher than was reached in the irradiation experiment. Also, continuous stirring of the solution in the ex-situ experiment increased the mass transfer of the oxidant $\left(\mathrm{H}_{2} \mathrm{O}_{2}\right)$ to the electrode surface. When the magnetic stirrer was turned off (see Fig. 5) the corrosion potential immediately fell to more negative values, apparently because the $\mathrm{H}_{2} \mathrm{O}_{2}$ in the diffusion layer next to the copper electrode was consumed by decomposition into $\mathrm{H}_{2} \mathrm{O}$ and $\mathrm{O}_{2}$, and the reaction became diffusion limited.

In closed systems consisting of $\mathrm{J}-13$ well water and moist air: CDAlO2 was found to be much more susceptible than AISI 316L stainless steel to vapor phase attack in irradiated environnents. This is likely a result of the known formation of ozone and various oxides of $n i-$ trogen as well as nitric acid in systems containing $\mathrm{O}_{2}, \mathrm{~N}_{2}$ and $\mathrm{H}_{2} \mathrm{O}$ vapor. 15,16 The products are corrosive to copper but much less so to stainless steel. A photograph of a sample of the vapor phase corrosion of CDAl02 is shown in Fig. 6 . In this case, the left half of the length of the rod was imnersed in J-13 well water and the right half to the atmosphere above it in a sealed glass tube. The total duration of the irradiation vas 15 days. Although oxidation of both the vapor and solution phase surfaces is apparent, much more severe oxidation has occurred in the vapor phase. The oxide that formed was identified as $\mathrm{Cu}_{2} \mathrm{O}$ by $x$-ray diffraction. Previous studies of the irradiation of copper in moist air without a liquid phase have revealed formation of what appeared to be copper hydroxide nitrate, $\mathrm{Cu}_{2}(\mathrm{OH})_{3} \mathrm{NO}_{3}$ (also known as basic copper nitrate), instead of $\mathrm{Cu}_{2} \mathrm{O} 4,17$ The absence of detectable nitrate in the present case may have resulted either from the relutively snall dose or from dissolution of some of the nitrogenous gases in the liquid phase. preventing their reaction with the surface of the sample in the vapor phase region. It is known that reaction of pure $\mathrm{NO}_{2}$ with copper produces $\mathrm{Cu}_{2} \mathrm{O} .18$

Electrochemical Mechanisms The elestrochemistry of potential 
waste container materials relevant to corrosion processes in irradiated environments is obviously very complex. In what follows, some of the major points are discussed. Space does not allow an elaborate discussion here. The interested reader can find a more detailed discussion elsewhere.10

It seems likely from the above that the radiolytically generated $\mathrm{H}_{2} \mathrm{O}_{2}$ and probably also the oxidizing transient radical $\mathrm{OH}$ play important roles in the electrochemistry of metals in irradiated environments. The initial rapid rise of potential for AISI 316L stainless steel and CDAl02 copper upon initiation of irradiation is most likely due to the production of these species in the solu$t$ ion layers next to the electrode surface.

It has been recognized for a long time that copper is catalytic towards the decomposition of hydrogen peroxide, while stainless steels are only mildly so. 19 In acidic media, $\mathrm{H}_{2} \mathrm{O}_{2}$ has been shown to increase the rate of the autodissolution process of copper by a catalytic mechanism. 20 In this mechanism, cupric ions are formed from the solution phase oxidation of cuprous ions. The cupric ions can then act as cathodic depolarizers to accelerate the corrosion process.

The behavior of the copper corrosion potential upon initiation of irradiation is interesting. The initial large positive jump in potential indicates a rapid response to the presence of $\mathrm{H}_{2} \mathrm{O}_{2}$ and $-\mathrm{OH}$ radicals. Then, the almost immediate negative decline in potential may indicate a decreased catalytic efficiency for reduction of $\mathrm{H}_{2} \mathrm{O}_{2}$, and may correspond to the oxidation of the surface or alteration of the oxide film on copper (e.g., by adsorption of intermediates). Visually, the surface of copper is observed to be oxidized under irradiation. The appearance of the surface of AISI 316L stainless steel is not nearly as affected by irradiation as is that of copper.

of course, the corrosion potential under irradiation will be determined by a superposition of $a=1$ the anodic le.g., metal dissolution) and cathodic processes occurring on the surface. Possible sets of anodic and cathodic reactions for stainless steels under the conditions employed in these experiments are given in Table II. These reactions will probably dominate under gamma irradiation of aerated aqueous systems similar to J-13 well water and its concentrated $(10 x, 100 x)$ forms, when the $\mathrm{pH}$ is neutral to mildiy alkaline. Analogous reaction sets can be written for copper.

In the first cathodic redox reaction given in Table II (that involving an equilibrium between adsorbed hydroxyl radicals and hydroxide ion in solution), the adsorbed hydroxyl radicals can come from the surface- catalyzed decomposition of $\mathrm{H}_{2} \mathrm{O}_{2}$, i.e.,

$$
\mathrm{H}_{2} \mathrm{O}_{?}(\mathrm{aq})+2(\mathrm{OH}) \mathrm{ads}
$$

or by direct adsorption of transient radiolytic - On radicals. This redox reaction has previously been proposed to account for the open-circuit potentials observed for Pt in high-purity aqueous solutions of $\mathrm{H}_{2} \mathrm{O}_{2} .{ }^{21} \mathrm{~A}$ mechanism for the cyclical catalytic decomposition of $\mathrm{H}_{2} \mathrm{O}_{2}$ on Pt that involves adsorbed species $1 \cdot 0 \mathrm{H}$ and $\mathrm{HO}_{2}$ ) resulting from the electrochemical discharge of $\mathrm{H}_{2} \mathrm{O}_{2}$ has also been advanced to account for the observed opencircuit behavior of $\mathrm{Pt}$ in aqueous $\mathrm{H}_{2} \mathrm{O}_{2}$ solutions, particularly at higher $\mathrm{pH} .22$ In the cyclical mechanism, $\mathrm{H}_{2} \mathrm{O}$ and the additional cathodic depolarizer $\mathrm{O}_{2}$ are liberated. This cyclical mechanism is probably the mere likely pathway.

In analogy to these studies on $\mathrm{Pt}$, similar mechanisms may explain the observed results for stainless steel and for $\mathrm{Cu}$ and its alloys in irradiated aqueous solutions. However, the situation will surely be more complex for tirese materials in our environments than for $\mathrm{Pt}$ in high-purity aqueous solutions of $\mathrm{H}_{2} \mathrm{O}_{2}$. This will result from the additional anodic reactions of metal dissolution and the presence of other species capable of participating in redox reactions (e.g., $\mathrm{HCO}_{3}^{-}$and $\mathrm{NO}_{3}$ ). In addition, for copper and its alloys, the presence of $\mathrm{H}_{2} \mathrm{O}_{2}$ may catalytically accelerate the autodissolution process via the following reaction series:

$$
\begin{aligned}
& \mathrm{Cu}+\mathrm{Cu}^{+}+\mathrm{e}^{-} \\
& \mathrm{Cu}^{+2}+\mathrm{e}^{-}+\mathrm{Cu}^{+}
\end{aligned}
$$


with $\mathrm{Cu}^{+2}$, acting as an oxidant, being generated $\mathrm{from}$ the solution reaction:

$$
\mathrm{Cu}^{+}+\mathrm{H}_{2} \mathrm{O}_{2} \rightarrow \mathrm{Cu}^{+2}+\mathrm{OH}+\mathrm{OH}^{-}
$$

As mentioned above, the open circuit behavior as a furcicion of time during irradiation is somewhat different for copper than for stainless steels. Upon initiation of irradiation the potential immediately shifts by about $100 \mathrm{mV}$. The potential then declines to less positive values. This may indicate a decreased catalytic efficiency for $\mathrm{H}_{2} \mathrm{O}_{2}$ decomposition, either because of the oxidation of the copper surface or perhaps because of the adsorption of species such as $\cdot \mathrm{OH}$ which block surface sites. 20

\section{SUMMARY}

Gamma irradiation increases the oxidizing nature of tile aqueous solutions used in this study through production of - $\mathrm{OH}$ and $\mathrm{H}_{2} \mathrm{O}_{2}$. These species probably account for the observed positive corrosion potential shifts for stainless steels, copper, and copper alloys. The observed corrosion potentials are mixed potentials, resulting from a complex superposition of all the cathodic processes (e.g., reduction of ${ }^{\circ} \mathrm{OH}, \mathrm{O}_{2}$, and $\mathrm{H}_{2} \mathrm{O}_{2}$ ) and anodic processes (e.g., metal dissolution) occurring at the metal surface.

Copper and its alloys are known to be very catalytic towards the decomposition of $\mathrm{H}_{2} \mathrm{O}_{2}$, a radiolytic product. In solution, the surfaces of copper and its alloys appear to be more affected (oxidized) in irradiated environments than those of stainless steels. With regard to corrosion potential shifts under irradiation, the sitme general behavior as for stainless stefls (positive corrosion potential shifts) is observed initially. However, the corrosion potentials then decline to relatively less positive values. This may be related to a decreased efficiency for catalytic decomposition of $\mathrm{H}_{2} \mathrm{O}_{2}$, resulting from surface oxidation or adsorption of intermediate species.

In addition to the work reported above, preliminary results from other experiments involving stainless steels, copper, and copper alloys in $\mathrm{J}-13$ well water and its concentrated forms (to $100 x)$, show that the positive corrosion potential shifts observed under irradiation are ..ot sufficient $t c$ shift the metal into the pj.tting corrosion regime. Detailed studies are cirrently underway to evaluate the effect of irradiation on localized corrosion susceptibility (e.g.. to pitting and crevice corrosion) of prospective nuclear waste container materials.

\section{REFERENCES}

1. J. N. Hockman and W. C. O'Neal, Lawrence Livermore National Laboratory Report UCRL-89820 Rev. I, February 1984 .

2. N. Fujita, M. Akiyama, and T. Tamura, Corrosion, vol. 37, p. 335 (1981).

3. T. Furuya, T. Fukuzuka, K. Fujiwara, and H. Tomari, Kobe Res. Dev., Vol. 33 , p. 43 (1983).

4. A. V. Byalobzheskii, "Radiation Corrosion", Israel program for Scientific Translations, Jerusalem, 1970.

5. K. Ishigure, N. Fujita, T. Tamura, and $K$. Oshima, Nuclear Technology, vol. 50, p. 169 (1980).

6. G. H. Cartledge, Nature, Vol. 186, p. 370 (1960).

7. S. Uchida, E. Ibe, and R. Katsura, Rad. Phys. Chem., Vol. 22, p. 515 (1983).

B. W. E. Clark, J. Electrochem. Soc., Vol. 105, p. 483 (1958).

9. W. G. Burns, W. R. Marsh, and W. S. Walters, Radiat. Phys. Chen., Vol. 21, p. 259 (1983).

10. R. S. Glass, G. E. Overturf, R. A. Van Konynenburg, and R. D. McCright, Lawrence Livermore National Laboratory Report UCRL-92311, February 1985.

11. C. J. Hochanadel, J. Phys. Chem., vol. 56, p. 587 (1952). 
12. A. O. Allen, "The Radiation Chemistry of Water and Aqueous Solutions," D. Van Nostrand and Co., Inc., Princeton, N.J., 1961.

13. J. W. T. Spinks and R. J. Hoods, "An Introduction to Radiation Chemistry, 2nd edition", John Wiley and Sons, New York, 1976.

14. R. M. Sellers, Analyst, Vol. 105, p. 950 (1980).

15. S. C. Lind, "Radiation Chemistry of Gases," Reinhold Publishing Corp., New York, 1961.

16. W. G. Burns, A. E. Hughes, J. A. C. Marples, R. S. Nelson, and A. M. Stonenam, Nature, Vol. 295, p. 130 (1982).

17. W. Primak and L. Fuchs, Physics Today, Vol. 7, p. 15 (1954).

18. J. R. Park and J. R. Partington, J. Chem. Soc., Vol. 125, P. 72 (1924).

19. J. S. Reichert and R. H. Pete, Chem. Eng., Vol. 54, p. 213 (1947).

20. A. I. Molodov, G. N. Markos'yan, and V. V. Losev, Elektrokhimiya, Vol. 18, p. 1186 (1982).

21. J. O'M. Bockris and L. F. Oldfield, Trans. Faraday Soc., vol. 51, p. 249 (1955).

22. R. Gerischer and $H$. Gerischer, Z. Phys. Chem., Vol. 6, p. 178 (1956). 


\begin{tabular}{lc}
$\begin{array}{c}\text { TABLE I - Average Composition of } \mathrm{J}-13 \\
\text { Well Water (based upon measurements } \\
\text { using ICP-OES, IC, and Technicon } \\
\text { AutoAnalyzer) }\end{array}$ \\
\hline Species & $\underline{(\mathrm{mg} / \mathrm{L})}$ \\
\hline & 125 \\
$\mathrm{HCO}_{3}^{-}$ & 19 \\
$\mathrm{SO}^{2-}$ & 9.6 \\
$\mathrm{NO}_{3}^{-}$ & 6.9 \\
$\mathrm{Cl}^{2}$ & 2.2 \\
$\mathrm{~F}^{-}$ & 44 \\
$\mathrm{Na}^{+}$ & 12.5 \\
$\mathrm{Ca}^{2+}$ & 5.1 \\
$\mathrm{~K}^{+}$ & 1.9 \\
$\mathrm{Mg}^{2+}$ & 27 \\
$\mathrm{Si}^{+}$ & \\
\hline
\end{tabular}


TABLE II - Possible Redox Reactions in Gamma-Irradiated J-13 Water

Cathodic reations:

$(* \mathrm{OH})_{\mathrm{ads}}+\mathrm{e}^{-}+\mathrm{OH}^{-}$

$\mathrm{O}_{2}+2 \mathrm{H}_{2} \mathrm{O}+4 \mathrm{e}^{-}+4 \mathrm{OH}^{-}$

$\mathrm{O}_{2}^{-}+\mathrm{H}_{2} \mathrm{O}+\mathrm{e}^{-} \rightarrow \mathrm{HO}_{2}^{-}+\mathrm{OH}^{-}$

(small contribution)

$\mathrm{HO}_{2}^{-}+\mathrm{H}_{2} \mathrm{O}+2 \mathrm{e}^{-} \rightarrow 3 \mathrm{OH}^{-}$

(very small contribution)
Anodic reactions:

$\mathrm{Fe}+\mathrm{Fe} e^{+2}+2 \mathrm{e}^{-}$

$\mathrm{Cr}+\mathrm{Cr}^{+3}+3 \mathrm{e}^{-}$

$\mathrm{Ni} \rightarrow \mathrm{Ni}^{+2}+2 \mathrm{e}^{-}$ 
REPPODUCED FROM
BEST AVAILABLE COPY

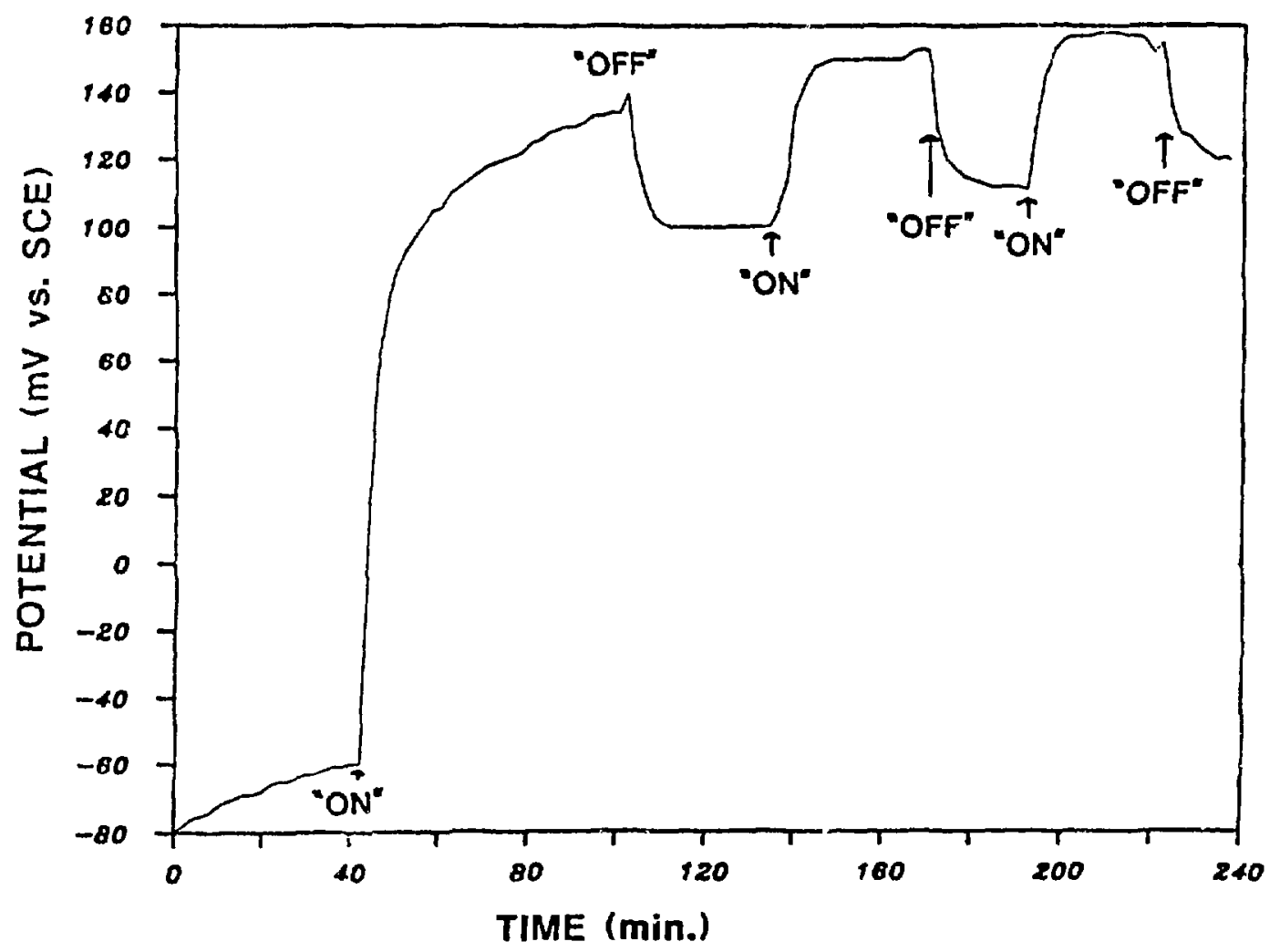

FIG. 1. Corrosion potential behavior for AISI 316L stainless steel in 10X concentrated J-13 well water under gamma irradiation. The solution was not exposed to irradiation prior to initiation of the first "on/off" irradiation cycle. 


\section{REPRCDUCED FROM \\ BEST AVAILABLE COPY}

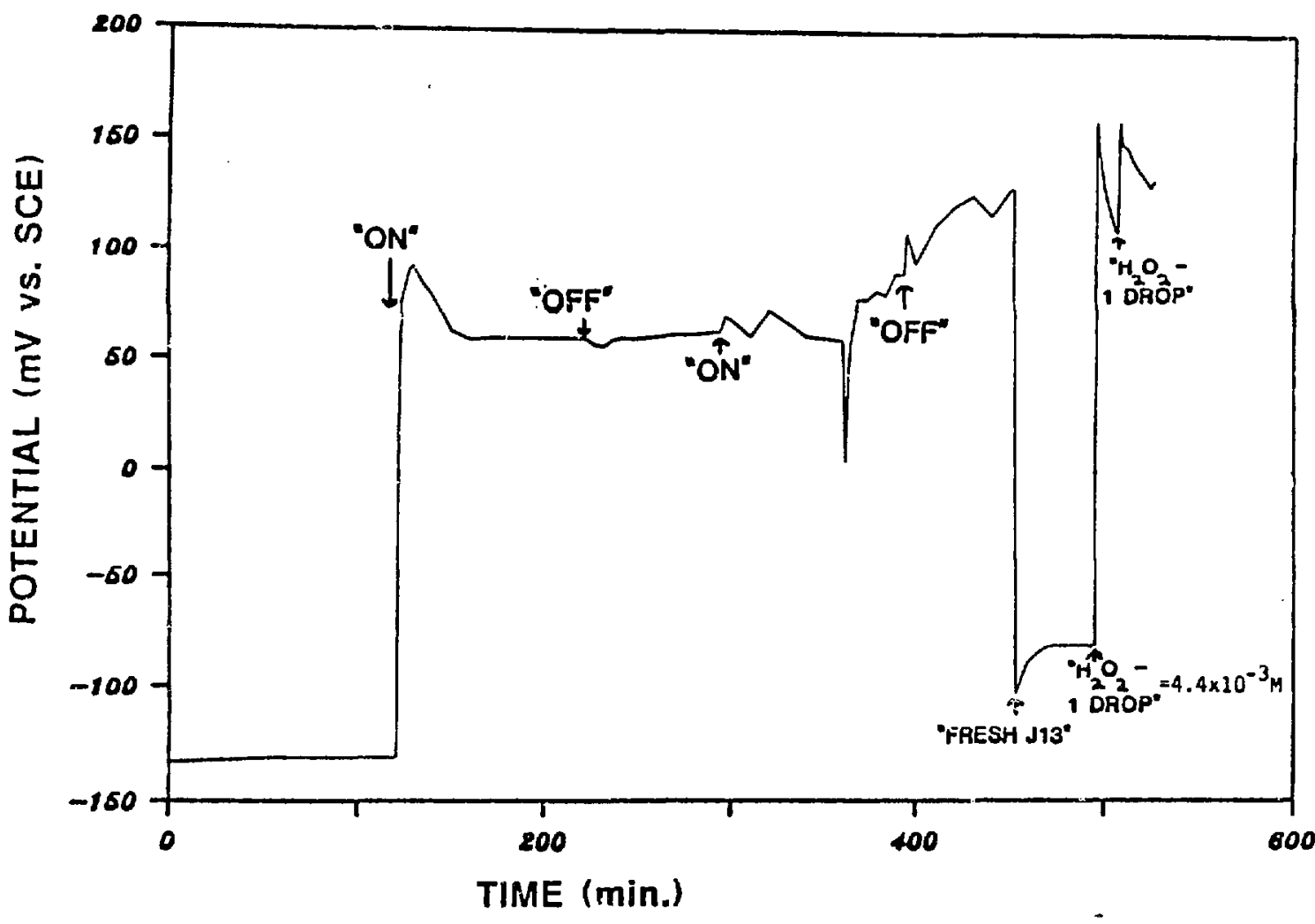

FIG. 2. Corrosion potential behavior for AISI 316L stainless steel in gamme-irradiated J-13 well water. Following the last "off" half-cycle the irradiated solution was decanted and replaced by a fresh, unirradiated solution. Following this, two drops of $\mathrm{H}_{2} \mathrm{O}_{2}$ (from a 30 solution) were added successively. One drop of $\mathrm{H}_{2} \mathrm{O}_{2}$ represents a resulting solution concentration of $4.4 \mathrm{mM}$. 


$$
\begin{aligned}
& \text { REPPODUCED FROM } \\
& \text { BEST AVAILABLE COPY }
\end{aligned}
$$

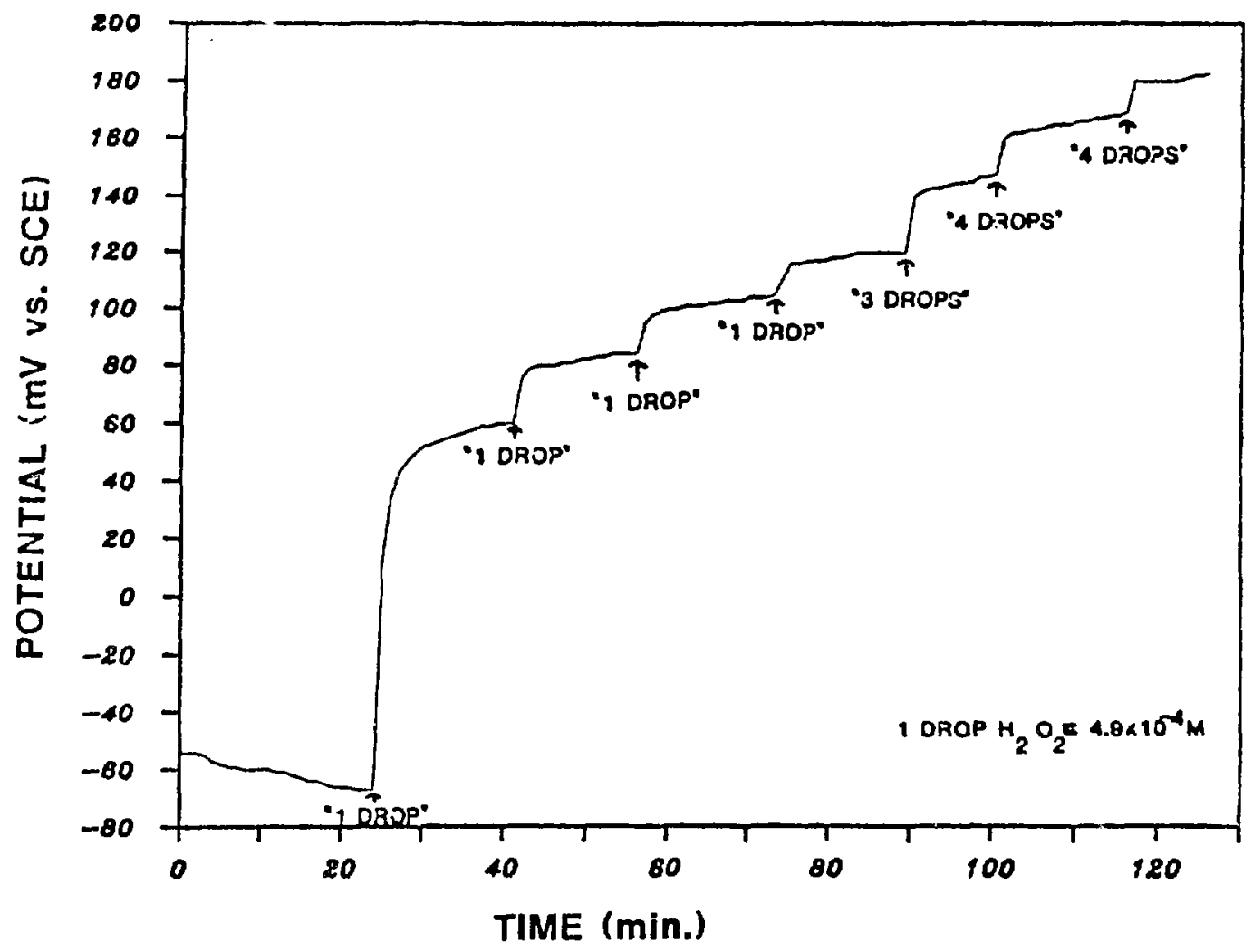

FIG. 3. Response of the corrosion potential for AISI 316L stainless steel in unirradiated $\mathrm{J}-13$ well water to which successive additions of $\mathrm{H}_{2} \mathrm{O}_{2}$ were made. In this figure, one drop of $\mathrm{H}_{2} \mathrm{O}_{2}$ (from a 30 solution) represents a resulting solution concentration of $0.5 \mathrm{mM}$. The solution was continuously stirred by a magnetic stirrer throughout the experiment. 
F'MAODUCED F'

BEOT AVAILABLE CU T

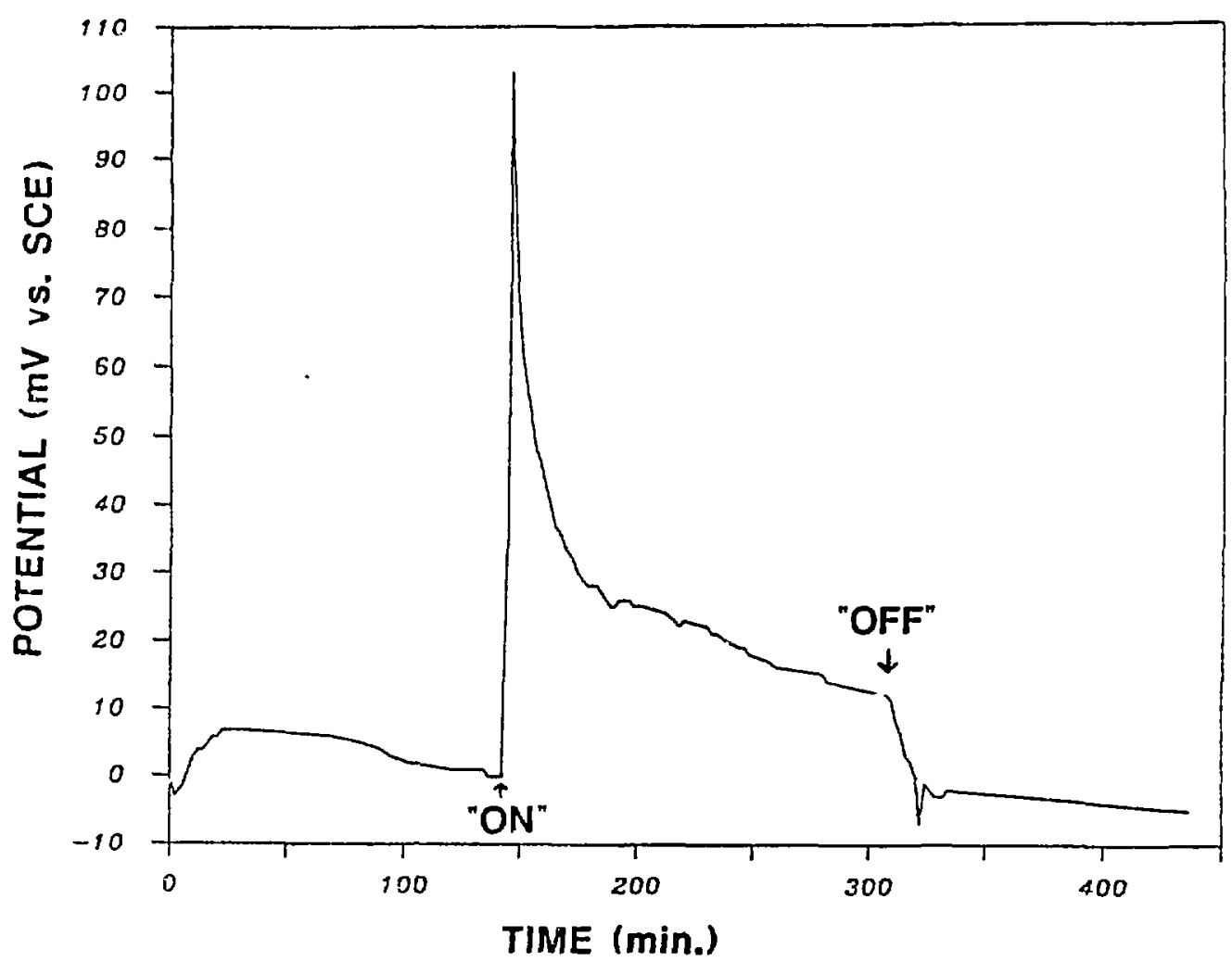

FJG. 4. Corrosion potential behavior for CDA102 copper irradıated in $j-i j$ well water at $3.3 \mathrm{Mrad} / \mathrm{h}$. 


$$
\begin{aligned}
& \text { REPRODLICED FNO } \\
& \text { BEST AVAILABLE COU. }
\end{aligned}
$$

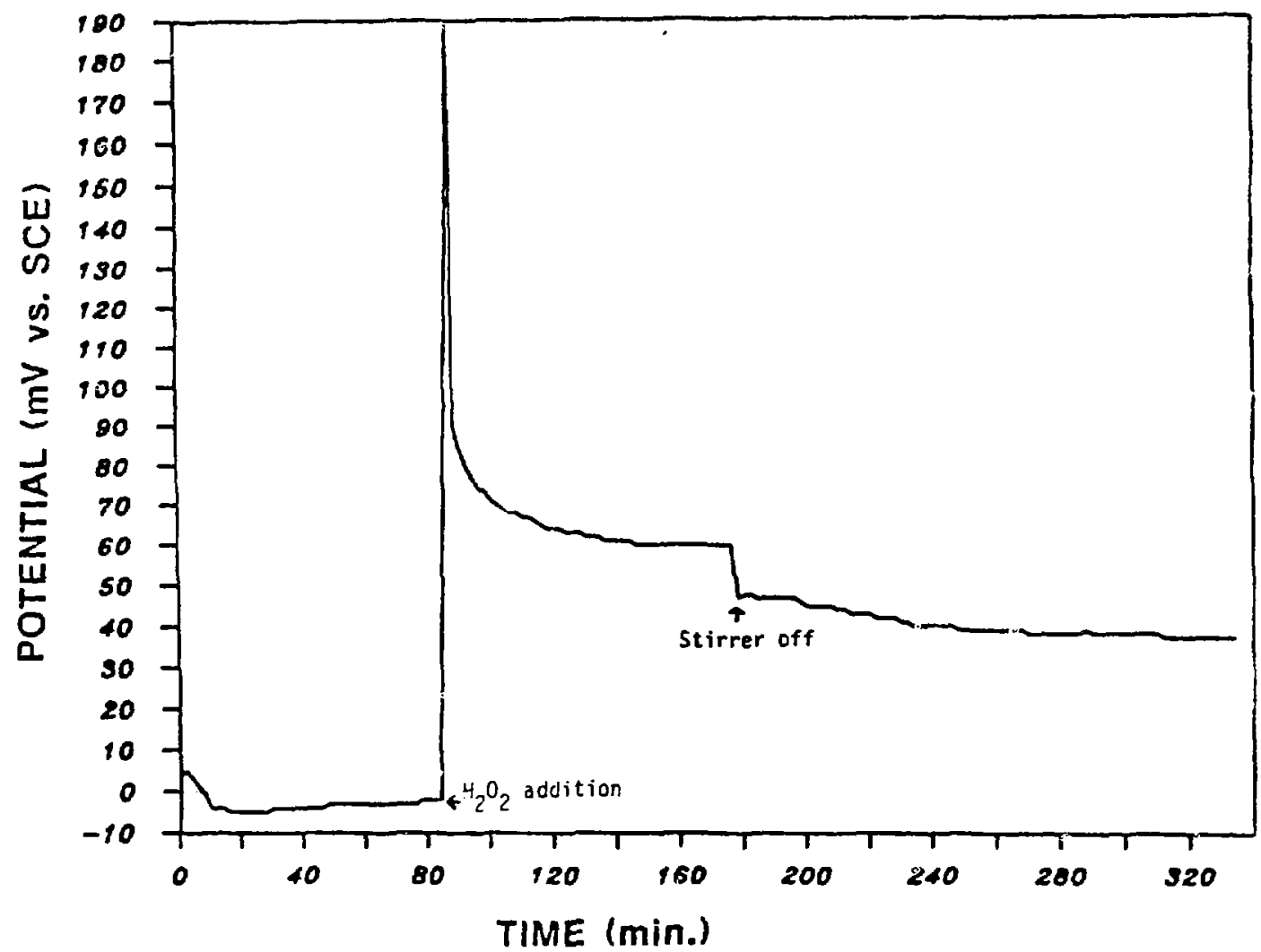

FIG. 5. Response of the corrosion potential for CDA102 copper in unirradiated J-13 well water to which one drop of $308 \mathrm{H}_{2} \mathrm{O}_{2}$ solution was added, corresponding to a solution concentration of $0.5 \mathrm{mM}$. The solution was stirred until indicated on the Figure. 


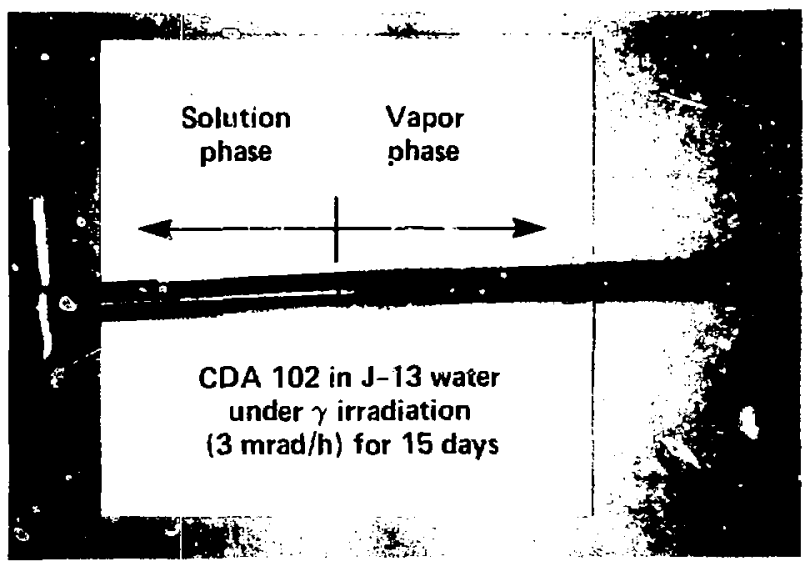

FIG. 6 Photograph of CDAl02 copper rod that was gamma-irradiated at $3 \mathrm{Mrad} / \mathrm{h}$ for 15 days. Left half was submerged in $\mathrm{J}-13$ well water, and right half was in contact with moist air during irradiation. 